Sub-Regionalism in the Newly Independent States

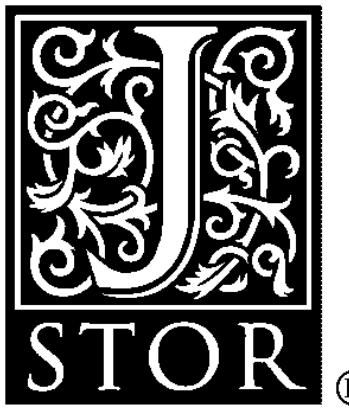

Author(s): Ian Bremmer and Alyson Bailes

Source: International Affairs (Royal Institute of International Affairs 1944-), Vol. 74, No. 1, (Jan., 1998), pp. 131-147

Published by: Blackwell Publishing on behalf of the Royal Institute of International Affairs Stable URL: http://www.jstor.org/stable/2624671

Accessed: $17 / 06 / 2008$ 06:20

Your use of the JSTOR archive indicates your acceptance of JSTOR's Terms and Conditions of Use, available at http://www.jstor.org/page/info/about/policies/terms.jsp. JSTOR's Terms and Conditions of Use provides, in part, that unless you have obtained prior permission, you may not download an entire issue of a journal or multiple copies of articles, and you may use content in the JSTOR archive only for your personal, non-commercial use.

Please contact the publisher regarding any further use of this work. Publisher contact information may be obtained at http://www.jstor.org/action/showPublisher?publisherCode=black.

Each copy of any part of a JSTOR transmission must contain the same copyright notice that appears on the screen or printed page of such transmission.

JSTOR is a not-for-profit organization founded in 1995 to build trusted digital archives for scholarship. We enable the scholarly community to preserve their work and the materials they rely upon, and to build a common research platform that promotes the discovery and use of these resources. For more information about JSTOR, please contact support@jstor.org. 


\title{
Sub-regionalism in the
}

\section{Newly Independent States}

\author{
IAN BREMMER \& ALYSON BAILES
}

Most analyses of European security during the I990s have been dominated by two themes: the Western-style integration process and the strains caused by its planned extension to the east; and the proliferation of 'new nationalisms' with their attendant conflicts-often involving the break-up or serious weakening of states themselves. Taken together with growing consciousness of transnational threats and global processes which can hardly be mastered even at the pan-European level, both trends have nurtured pessismism about the viability of traditional nation-states and the adequacy of institutions based upon them. ${ }^{\mathrm{I}}$ They also help explain why, so short a time after the collapse of a major inter-bloc divide, Europe's security nightmares are still dominated by images of polarization, alienation and exclusion. New divisions seem impossible to avoid, yet are felt all the more painfully for the honeymoon hopes of wholeness in 1989-90. It is hard to ignore the coincidence of several indicators- 'integratability', state cohesion, civilizational factors-which would point to a fundamental rift along fault-lines somewhere to the north of Serbia and west of Belarus. Yet even those who find themselves on the right side can hardly be at ease with the prospect of a permanent frontier between 'cosmos and chaos'2 lying so close to home, and in a continent which so recently believed it could set the world an example of reunion through detente.

According to temperament, analysts unhappy with these trends have sought answers in the freezing and consensual management of present divides; ${ }^{3}$ in a

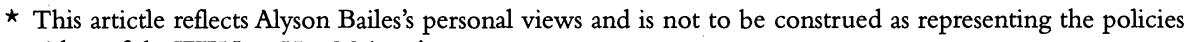
either of the WEU or Her Majesty's government.

I A particularly succinct example is the report 'A future security agenda for Europe', presented to the OSCE by an Independent Working Group and published by the Stockholm International Peace Research Institute in October 1996.

2 See Ola Tunander, 'Post-Cold War Europe: a synthesis of a bipolar friend-foe structure and a hierarchic cosmos-chaos structure?' in Ola Tunander, Pavel K. Baev and Victoria Ingrid Einagel, eds, Geopolitics in post-Wall Europe (Oslo: Peace Research Institute, 1997).

3 This is essentially the approach of such US analysts as Charles Kupchan (see e.g. 'Regionalizing Europe's security: the case for a new Mitteleuropa', in Edward D. Mansfield and Helen Z.V. Miller, eds, The political economy of regionalism (New York: Columbia University Press, 1997) and Michael Mandelbaum, The dawn of peace in Europe (New York: Twentieth Century Press, 1996). 
fresh attempt to devise inclusive, genuinely pan-European systems; or in a leap upwards to a new, 'globalized', less state-dependent mode of security management. One problem with all three approaches is that they are still over-focused on what is commonly thought of as European territory and-even if they do take some account of Ukraine-cannot easily be used to generate solutions for the Newly Independent States stretching along the boundary between Europe and Asia. The neo-realist approach would imply either consigning these republics indefinitely to the Russian sphere, or exploiting them as the rear echelon of a new containment strategy. Current ideas for new inclusive 'cooperative security' regimes (such as NATO's Euro-Atlantic Partnership Council or the OSCE 'Security Model'4) do little to accommodate the special needs, security priorities and contributions of the NIS, and even the most liberal vision of 'permanent enlargement' is unlikely to stretch to Uzbekistan. As for globalizing approaches, the NIS region unhappily combines some of the clearest examples of collapse or inadequacy of traditional states with the strongest material and psychological barriers to effective transnational solutions.

There is one feature of the post-Cold War European security scene still unnoticed by many analysts which on the face of it might be more readily transplanted to regions further south and east, precisely because its strength lies in overcoming divisions. Since 1989 , six new sub-regional' ${ }^{5}$ cooperation groups have arisen on European territory from the high north to the Black Sea, and five of them are still flourishing: the Barents Euro-Arctic Council (BEAC), Council of Baltic Sea States (CBSS), Central European Free Trade Area (CEFTA), Central European Initiative (CEI) and Black Sea Economic Cooperation (BSEC). All of these contain some combination of present NATO/EU members, or leading aspirants, alongside countries not expected or not wishing to join the 'first wave' of enlargement (including the non-aligned). The Russian Federation is a founding member and constructive player in three of the groups, the BEAC, CBSS and BSEC; Ukraine and Belarus belong to the $\mathrm{CEI}$ and Ukraine to the BSEC also. All the former Yugoslav republics belong to the CEI except Serbia/Montenegro, and the latter's readmission is now back on the CEI agenda. ${ }^{6}$ These groups are thus already bridging Europe's emergent divides as well as the earlier Cold War ones. They defy the cosmos-chaos duality by showing the possibility of non-zero-sum cooperation between integrated and non-integrated, unitary and fissile, Christian and non-Christian states. Because their work typically involves considerable 'bottom-up' participation by regional authorities, social/professional groups and NGOs, they also

4 Declaration on a New Model of Security for Europe in the Twenty-first Century, adopted at the OSCE Summit meeting in Lisbon, 2-3 December I996.

5 'Sub-regional' is used here as a practical coinage, with no international legal significance, to describe formally constituted intergovernmental groupings which cover a geographically coherent area smaller than any of Europe's 'region-wide' organizations (OSCE, Council of Europe, NATO, EU).

6 The CEI Summit of November 1996 decided that Serbia/Montenegro would be readmitted 'when possible' and that this would be the last extension of CEI membership. 
offer an example of smooth bridging between the international, state-level and sub-state modes of operation in the search for added value and the effort against transnational threats.

During 1996-7 there has been growing political and institutional recognition in Europe of the value of these existing sub-regional groups, fuelled especially by interest in their capacity to cushion or mediate the tensions of NATO/EU enlargement. ${ }^{7}$ Parallels have been recognized between them and the dynamics of emerging regional cooperation in other parts of the world, and dialogue meetings have been set up for example between the CBSS and ASEAN, or CEI and Mercosur. But their relevance to the NIS area, though acknowledged at least by the OSCE, has yet to be systematically explored. Any attempt to do so must, of course, start with the recognition that no fixed 'model' of subregionalism is likely to survive transplantation to this much trickier terrain. Within Europe itself the scale, agendas and methods of sub-regional work vary widely from one group to another, and the spectrum of variation will need to be stretched further to devise anything that can genuinely help with the challenge of former Yugoslavia. What may be helpful is to clarify the main generic contributions which the five groups mentioned above can make and are making to security in their own territories, and extract some initial lessons to test against new areas for application.

\section{The central/east European experience}

Sub-regional groups in Europe do not and should not attempt to be primary providers of security. They are both too small (strategically unbalanced) and too large (diverse) to be able to convey 'hard' defence guarantees, create joint military units, negotiate arms reductions or enforce the end of overt conflicts. Their impact on security is more oblique and subtle and starts with their 'existential' significance, as groups of states which recognize themselves as sharing some elements of community and can thus prima facie define their national identity as complementary, rather than adversarial, to their neighbours'. Regular meetings and the creation of personal ties encourage esprit de corps, create channels of communication which might also be used to defuse crises, and should at least unconsciously strengthen taboos against the use of force.

\footnotetext{
7 At the OSCE seminar on sub-regional security held in Vienna on 2-4 June I997 as part of a continuing work programme on the new security model, much of the time was devoted to discussion of sub-regional organizations; and in May 1997 the European Commission published a paper evaluating the BSEC which advocated EU representation in its organs (such as already exists in the BEAC and CBSS). The Permanent Council of the Western European Union held two brainstorming sessions on the security value of sub-regional cooperation during I996. The Institute for EastWest Studies conducted a major research and policy-making project on 'Multi-layered integration: the sub-regional dimension' from June I996 to June 1997: pending publication in book form of the project findings, key points will be found in the article by Alyson J. K. Bailes, 'Sub-regional organizations: the Cinderellas of European security', NATO Review 2, March 1997.
} 
The tangible activities of these groups tend to be focused on economic development, transnational planning for infrastructure and transport, environmental problems and natural resource management, and human contacts especially in the fields of tourism, culture, and education. The development of joint programmes and realization of added value through cooperation creates interdependence of a kind that bolsters stability. Border regions may profit especially, becoming more self-reliant and more reconciled to their lot, as nonstate actors gain freedom to create their own transborder links. The Norwegian-Russian frontier, for example, is now managed by a joint border post and witnesses hundreds of peaceful crossings a day although it constitutes the one remaining direct contact-point between Russian territory and NATO. Where such easy, open conditions develop along borders the position of any ethnic minorities living outside their 'parent' state can clearly be much improved; and sub-regional groups have often devoted explicit effort to guaranteeing minorities' rights, as for example through the CBSS's creation of a special commissioner for this subject or the CEI's adoption of a legal instrument providing particularly detailed safeguards.

Sub-regionalism can also help meet the multifunctional demands of modern security management in more direct ways, notably by developing new principles and mechanisms of cooperation on 'new threats' such as terrorism, organized crime, drugs and other smuggling; natural and man-made accidents and the consequent need for humanitarian aid; refugeeism and uncontrolled migration. Since many of these problems come to a head at borders, cooperative frontier management is an important theme and has been developed particularly far by the CBSS, drawing on successful local initiatives such as the links between Russian, Finnish and Estonian border guards. The symbolism of keeping borders robust but permeable for honest trade is clearly of special value in the context of enlargement's 'dividing lines', and it is not entirely coincidental that several of the existing sub-regional groups have made plans to intensify their work just as NATO's first expansion approaches. Whether they place the emphasis on environmental challenges, as in the Northern groups, or free trade and joint investment, as in the BSEC, ${ }^{8}$ or whether they seek to enlarge their cohesive effects by taking in new members, as CEFTA has been doing, ${ }^{9}$ they all appear (so far) to have both the will and means to keep peaceful cooperation flourishing across potential divides. In the process, they may also help as few other instruments can to restrain temptations to backlash by the disappointed, or arrogance and selfishness by the states which win new guarantees.

8 For a factual summary of recent developments and forward plans in the BEAC, CBSS and BSEC see Erik Hansen, ed., Cooperation in the Baltic Region, the Barents Region and the Black Sea Region (Oslo University: Norwegian Institute for Applied Social Science, 1997), FAFO Paper no. 4.

9 Slovenia joined CEFTA in 1996 and Romania joined in 1997; other applications are pending from Bulgaria, the Baltic states and Ukraine. These accessions give CEFTA new value as a way of maintaining ties between states which may be separated by NATO's first enlargement decisions, and could also shift the odds in favour of CEFTA's continuing to exist in some form even after 'first-wave' accessions to the EU. 
Such an array of benefits, at modest cost (for most CEE sub-regional groups operate on a voluntary basis without even a secretariat), ought to make the subregional model particularly appealing to the Newly Independent States. But there is obvious need for caution in applying the lessons of 'core' Europe to sub-regions further afield. After all, the creation of the CEE groups was directly linked with the specific historical effects attending the collapse of the NATO/Warsaw Pact confrontation and has been further spurred by the dynamics of NATO enlargement: neither of these processes has had the same impact (for good or ill) on areas further to the east and south. That caveat in mind, there are a few conclusions sufficiently generic to be worth bearing in mind when testing the cooperative potential of any other sub-region.

First, experience shows beyond all doubt that a 'top-down' political impulse from state leaders is needed to call a sub-region into formal existence. Each government must feel that it has more to gain from such a collective restructuring of the local environment than from unbridled power play. If governments are not motivated in these ways, no amount of yearning at grass-roots level, or of outside bullying, will achieve durable results; and coercion from within the region is an equally unsound basis. To secure anything like the full range of benefits indicated above, groups must therefore be voluntary in their creation, consensus-based in their operation and managed on a principle of (at least formal) equality.

Once embarked on the process, local states are also best placed to make the judgement on which fields offer the most potential added value from cooperation (with the least security risk), and thus what is the ideal functional profile of their group. Leaving out certain topics and being blind to certain (especially military) realities may actually be a shrewd tactic for success. ${ }^{\text {IO }}$ European experience underlines how much extra value in terms of democracy-building, welfare, security and protection of minorities can flow from the inclusion of 'bottom-up' elements, especially where structures are designed to boost transfrontier cooperation. But this cannot work unless central authorities feel secure in their own ultimate control and confident that neighbours will not exploit the new freedoms to seduce or tear away disputed territories. Sub-regional structures can ease centre-periphery tensions (within states, as within alliances) only if they do justice to the interests both of capitals and of border zones. Finally, and in face of all the stumbling-blocks posed for cooperation by suspicion, ignorance, past grievance and material barriers, few things have proved so successful as an appeal to the purse. Sub-regional groups have cohered and grown best where they have been able to embark rapidly on material joint

\footnotetext{
Io The BEAC coexists with a still huge concentration of conventional and nuclear weapons on the Russian part of its territory; Russia, Moldova, Georgia, Armenia and Azerbaijan all work together in the BSEC despite unresolved incidents of conflict between them; the BSEC's concentration on economic topics and 'new threats' has been deliberately maintained to avoid the breaches that could result from discussion of human rights issues, as well as classic security.
} 
projects creating added value and interdependence, funded either by resource transfers from their richer members or (as is more necessary in the south European groups) with help from the EU and international banks.

If these lessons are kept in mind, states of very different sizes and security allegiances should be able to coexist in sub-regional groupings without damage to their sovereignty. In the case of Europe's post-Cold War groupings, the consensus seems to have been that the larger sub-regional communities-an important part of whose mission is to civilize power relationships and relativize 'dividing lines' - can and should include major military powers like Russia. As noted above, the BEAC, CBSS and BSEC have done so since their inception and not even their smallest member has found cause to complain of the results. If anything, such groups have helped weaker states by 'multilateralizing' neighbourly relations and thus adding an extra layer of international scrutiny. Smaller sets of states-with similar politico-economic profiles and shared ambitions in the integration/globalization process - can legitimately set up sub-regional structures for more focused, practical aims as exemplified by the former Visegrad grouping and CEFTA.The two types of sub-regional group can coexist and flow across each others' boundaries provided two basic principles are observed: (a) decision-making processes must be transparent; and (b) no group should have goals directed against the security and independence of any of its neighbours. Indeed, an interlocking pattern of relationships where a given state may belong to one or more neighbourhood groups, take part in association/partnership schemes led by the 'core' European institutions, and be an active member of OSCE and the Council of Europe is emerging as perhaps the best paradigm for handling (if not resolving) the security concerns of nonintegrated central and east Europeans in an age of phased enlargement.

\section{Sub-regionalism from above: the Russia factor}

In the NIS, where NATO/EU enlargement looks more like part of a problem than a solution and the implications of integration itself are ambivalent, there is obvious reason for caution in applying these conclusions. The difference in local conditions can best be seen by considering the 'top-down' and 'bottomup' factors that have determined the course of multinational organizing processes in the area thus far. The most significant sub-regional player among the NIS is their former hegemon, the Russian Federation. Moscow's initial strategy was to treat the non-Russian states as a monolithic backyard in which Russia held a monopoly interest. This was the logic behind the 'near abroad' (blizhnee zarubezh'e), a Russian formulation of NIS relations indicating a 'less than foreign' policy. One consequence of this understanding was that Russian policy was uniformly conceived and applied throughout the NIS. This was evidenced most clearly through the creation of a post-Soviet confederation-the Commonwealth of Independent States (CIS) - within which all the countries of the near abroad were to develop strong economic, strategic and, eventually, 
political ties to the Russian state. ${ }^{\text {II }}$

Russia's strategy ran into difficulty in practice, as policies that worked well for one state were profoundly inappropriate for others. Such was the notable case of dual citizenship, promoted vigorously by Moscow throughout the NIS. The proposal originated in unlikely Kyrgyzstan, where a large, highly educated and urban Russian population was rapidly leaving the country. The Kyrgyz economy, already in disastrous shape, was made even worse by the sudden shortage of trained labour. For President Akaev, anything to make the Russians more comfortable and keep them in Kyrgyzstan was a good idea. But the logic of the near abroad dictated that Moscow's policies be applied evenly throughout the NIS; and dual citizenship made less sense outside Kyrgyzstan. In Kazakhstan, with a burgeoning and potentially secessionist Russian population to the north, and in Ukraine, with more than Io million Russians who were by and large integrating successfully, Moscow's dual citizenship policy was viewed as a provocation. ${ }^{\mathrm{I} 2}$ Both governments held firm in their opposition, and the prospects of a coherent 'citizenship regime' fell flat. ${ }^{\mathrm{I} 3}$

Countless other policies failed on similar grounds, as the steps to political, economic and military integration favoured by some states were opposed by others. Underlying the problem was the polarity of views regarding the CIS's purpose. For Russia, the Commonwealth was an institutional framework which permitted continued hegemony over former Soviet regions. In other words, it was an explicitly unilateral organization. For Ukraine, alternatively, the CIS was a transition mechanism enabling breakaway Soviet republics to attain full independence. Armenia viewed the CIS as an opportunity to ensure its own national security, particularly vis-à-vis the Azeris in the war over NagornoKarabakh. Kyrgyzstan saw membership as a vehicle for keeping its troubled economy afloat. Georgia, for its part, had no intention of joining, but was pressured by Russia under the spectre of civil war. Eventually, the CIS fell into two competing camps: one favouring tightened integration (Armenia, Belarus, Kazakhstan, Kyrgyzstan, Tajikistan) and one against (Azerbaijan, Georgia, Moldova, Ukraine, Uzbekistan, Turkmenistan). This process did create or recreate ties with real integrative significance, but they tended to link states in geographically scattered coalitions, and this lacy geometry was plainly at odds with the Russian 'all or nothing' approach.

\footnotetext{
II See the 'Draft concept of the foreign policy of the Russian Federation', International Affairs (Moscow), January 1993, as well as the presidential decree 'Strategic policy of the Russian Federation toward CIS member states', Rossiskaya gazeta, 23 Sept. 1995.

${ }^{12}$ See Lowell Barrington, 'The domestic and international consequences of citizenship in the Soviet successor states', Europe-Asia Studies 47: 5, I995, pp. 73 I-63.

13 Ironically, dual citizenship never even made it in Kyrgyzstan, where despite presidential favour, the parliament decided it was too great a concession to the Russians and rejected the measure. See $R F E / R L$ Daily Report, Is April 1993. Russia did, however, conclude an agreement with Turkmenistan on dual citizenship in December 1993: an agreement that had significantly less import given the lower numbers of Russians in Turkmenistan and the lack of a strong opposition to contest it. Itar-Tass, 23 Dec. I993, in FBIS-SOV-93-246, p. 78.
} 
The widening gap between Russian policy-making demands and implementation pushed Moscow towards a more differentiated, bilateral strategy. This dramatic, if long unavowed, change in policy profoundly affected the environment for NIS sub-regionalism. Overall, its principle has been straightforward: actively strengthening relations with those states most favourably disposed towards Russia, while tolerating higher levels of autonomy from others, and building in added safeguards for Russian national security by constructing 'leapfrog' alliances with non-CIS states on the far side of less amenable neighbours (Iran, India). The ultimate intention-tightly knit and comprehensive Russia-led integration-remained the same, but the near-term expectations were quite different. ${ }^{\mathrm{I}}$ Accordingly, Russia signed landmark political and economic agreements with Belarus-creating a titular political union and real strategic alliance of the two states-but accepted more modest economic agreements with neighbouring Ukraine. Yeltsin expected relations with Kazakstan to proceed 'along the Belarus model', but voiced no such inclination vis-à-vis the Uzbeks.

When Russian policy has been interventionist, it has, again, been adjusted region by region. Most analysts expected a hands-on Russian policy to be driven by issues of 'the greater Russian nation'. Moscow would thus intervene in those regions with the highest concentrations of Russian minorities: Transdniestrian Moldova, south-east Ukraine and Crimea, north-east Estonia, and north Kazakhstan. In reality, the Russian approach was always more pragmatic, and has moved sharply in the direction of caution over time (especially following the war over Chechnya). Russia intervened only when it had the opportunity to maintain influence in a region thought critically importanton strategic or economic as well as ethnic grounds-and when the risk of counter-involvement by outside powers was low. This effectively limited Russian options to the manipulation of power balances in the southern tier by playing major protagonists off against one another. This has essentially been the Russian role in Karabakh, Abkhazia and South Ossetia.

Moscow's change of strategy strengthened Russian relationships with several key post-Soviet countries. It moved away not just from the aspiration to a homogeneous 'near abroad', but also from the conventional regional divisions of post-Soviet analysis. More direct cost-benefit calculations cut across the categories of western NIS, Caucasus and Central Asia to create unorthodox new 'axes' such as Armenia-Belarus-Kazakhstan-Kyrgyzstan. The 'top-down' effects on sub-regionalism were correspondingly ambivalent: Russia's lock on the CIS had been broken, but a new polarity had been created which could set apart neighbours and bring together the geographically remote.

\footnotetext{
I4 This policy shift was reflected in a document drawn up by the Council on Foreign and Defence Policy led by Sergei Karaganov, deputy director of the Russian Academy of Sciences Institute of Europe and a member of Yeltsin's Presidential Council: 'Vozroditsya li soyuz?', Nezavisimaya gazeta, 23 May 1996.
} 


\section{Sub-regionalism from below: conflicts and complications}

The 'bottom-up' conditions for creating positive sub-regional mechanisms among the NIS are also dogged by a unique combination of difficulties. These may be divided roughly under three headings: endemic factors, degree of linkage with the main European organizations, and reactions to Russia's role.

Unlike most players in central Europe, the NIS are largely characterized by weak traditions of statehood and lack of international experience. The harsh environment of their recent development has accentuated tendencies to autocracy and centralization on the one hand and secessionism and ill-controlled frontiers on the other-and sometimes a daunting combination of the two. Such an inhospitable climate looks particularly unpromising for transplanting the CEE sub-regional model. ${ }^{\text {I5 }}$ Inchoate notions of statehood also make it hard for governments to grasp the 'everybody wins' thinking basic to CEE subregionalism, so that such initiatives as have been launched for (especially) southern tier cooperation have too often been competing, duplicatory and designed to please outside patrons more than neighbours.

Interstate relations have also been riven by conflict to a degree unknown in 'core' Europe outside the former Yugoslavia. Sometimes Russian coercion or destabilization was a direct cause, sometimes the course of conflict led states into opposing choices vis-à-vis Russian protection-in each case making free-wheeling local cooperation more difficult. Wars raging throughout the southern tier have gravely set back the chances of 'normal' international relations in that sub-region. Between Chechnya and its regional fallout, the struggle for independence in South Ossetia and Abkhazia, and the wars in Nagorno-Karabakh and Tajikistan, there has been little leisure to invest in sub-regionalism. As the one conflict directly engaging two states against each another, the case of Karabakh has demonstrated how political conflict can poison a rational course of sub-regional cooperation. Efforts to develop an Azeri oil pipeline through Armenia, forging regional economic ties and, accordingly, interdependence, are bedevilled by Armenia's occupation of roughly one-fifth of all Azeri territory and, most recently, the appointment of Karabakh's ultranationalist President Robert Kocharian as Armenian Prime Minister. ${ }^{\text {I }}$

Russia's own attitude to distributing the economic spoils of the region has compounded the problem through its divide-and-rule tactics. In hopes of securing influence over energy exploitation and transport, Russia has cut deals on delimiting the Caspian Basin with Turkmenistan, Iran, and

\footnotetext{
Is Differences of religion and culture are important but secondary to these structural constraints, given that, for example, Islamic and non-Islamic states have coexisted well in the Black Sea Economic Council.

${ }^{16}$ For more on the 'peace pipeline' see Robert Krikorian, 'Odd bedfellows: Armenia and Caspian oil', Analysis of Current Events (Association for the Study of Nationalities) 9: 2, Feb. 1997. On the Kocharian appointment, see Ian Bremmer and Cory Welt, 'Armenia's new autocrats', Journal of Democracy 8: 3, July I997, p. 89.
} 
Kazakhstan, designed inter alia to isolate Azerbaijan from its own neighbours and to queer the pitch for Azeri exploitation of its offshore oil reserves without Russian participation.

As an isle of stability in the south, Turkmenistan underscores the rule. Having no shared border with Russia, Turkmenistan's rugged terrain has been protected from direct intervention. Within the country, the strongest authoritarian regime in the NIS has made demands on the government few and the need for international cooperation small. Accordingly, Turkmenistan has seen its salvation precisely in the avoidance of neighbourhood ties.

The analytical model set out above suggested that the worst obstacles to sub-regionalism are best tackled through the power of the purse-often amounting to outright bribery by outsiders-but here again the relative misfortune of the southern tier is apparent. The absence of rich neighbours is compounded by the weaker role of European integrative bodies. The European Union's normative pull does not extend much further east than Ukraine, nor does its spending in support of economic reform and interdependence. The powerful effect exerted by hopes of eventual EU membership on states' sub-regional behaviour, seen particularly clearly in CEFTA but also in the measurable success of the EU's Stability Pact in damping CEE bilateral disputes, cannot be reduplicated in the NIS context.

This is not to say that NIS thinkers lack interest in the EU. Ukraine has expressed its interest in ultimate EU entry, and further east, Kazakh President Nazarbaev's visionary 'Eurasian Union' proposal-which seeks to create a multinational model beyond the CIS-was inspired by European experience. ${ }^{17}$ But the way that vision is interpreted by the NIS has often been part of the problem. The EU offers an economically focused, monolithic and invasive model of integration, demanding a high level of market sophistication, openness and readiness to compromise on sovereignty. It addresses political relations only as an implicit function and through weaker mechanisms, keeping internal conflict off the agenda partly because it is contained through NATO. It has not been a prime mover of bottom-up, cross-border and nongovernmental cooperation in its own sphere (which helps explain how the new CEE sub-regional groups have found their niche). All in all, it is not surprising if NIS policy-makers classify EU-style integration as an ideal unattainable for states at their economic level and irrelevant for their immediate political ills. And since the ideal blots out awareness of more modest sub-regional approaches, the calculation tends to be 'EU or nothing' with nothing as the result.

Russia re-enters the picture here, because while it has claimed to be pursuing CIS integration on the model of EU political union, its actions have deepened NIS convictions that local integration can have only one meaningone not to all tastes. Even leaving aside the nature of Russian integrative

\footnotetext{
${ }^{17}$ Kazakhstanskaya pravda, 7 June 1994.
} 
policy, the geostrategic environment in the heart of Eurasia is different from the western limb of the continent. The success of the EU has been based upon the principle of parity between state actors, an unsustainable assumption in CIS conditions. If significant relational dyads run through the EU's membership, the only relationships which have mattered in the NIS run directly to Moscow. More realistic models for regional structuring would be NAFTA or NATO, in which one state holds a majority of de facto influence-and leverage. But with all the irritation that Mexico or Britain may sometimes feel for Big Brother, these remain examples of voluntary pacts based on collective policies. CIS members do not perceive their own organization that way. Accordingly, the calculation above is often reduced to: EU integration unattainable, Russian integration bad, therefore better keep all ties to a minimum. So long as countries' integrative choices are for or against Russia-rather than the options CEE players have had to build their groups with or without Russia-insurmountable barriers between the NIS differently thinking neighbours will remain.

\section{Seeds of hope}

There is another aspect to the picture, but it is one visible only when preconceptions drawn from the CEE region are set aside. Positive preconditions for sub-regionalism in the NIS, especially the southern NIS, have sources that are also special to the region: the higher salience of non-traditional security threats; the scope for and attraction of cooperation with non-NIS neighbours; and the scale of involvement by outside capital with its 'globalizing' side-effects. Generally speaking, too, the geostrategic shadow of Russia creates a predisposition to diversifying local ties even while it places obstacles in their way. Friends of Russia look for balancing relationships lest friendship become too stifling; countries hoping to stay too slippery for the Russian grasp know themselves too weak to play this game in isolation. This connects neatly with the 'ganging-up' and 'multilateralizing' motives which have contributed to smaller CEE states' acceptance of sub-regionalism.

Non-traditional security issues (the environment, defence against pollution, water management, drug smuggling, organized crime, migration and refugeeism) provide a fruitful area for NIS discourse because the threat neither flows primarily from, nor can uniquely be resolved by, Moscow. ${ }^{18}$ Different as the needs and aims of states may be on specific resource or pipeline issues, they all have a prima facie interest in avoiding conflict in these spheres which would merely aggravate the challenges to their fragile statehood. Accordingly, there have been a number of voluntary moves to set up regimes for controlling organized crime, drug trafficking, international terrorism and illegal migration, as well as supporting economic development and environmental protection. For

\footnotetext{
${ }^{18}$ See Alyson Bailes and Ian Bremmer, 'Russia's total security environment', forthcoming in Security Dialogue, March 1998.
} 
example, a series of Central Asian summits on water management and the Aral Sea crisis-leading to an agreement by which each state pledged 0.3 per cent of its GNP to an environmental fund supporting the resolution-has advanced Central Asian state cooperation without arousing the ire of Russia. ${ }^{19}$ So too has the recently formed Central Asian Battalion-composed of forces from Kazakhstan, Kyrgyzstan, and Uzbekistan-for increasing and coordinating local peacekeeping endeavours. ${ }^{20}$

Another area of growth has been opened up by the blurring of borders between NIS states and their sub-regional counterparts outside the former Soviet Union. The obverse of intra-CIS differentiation provoked by new Russian policies has been a growing diversification of NIS cooperation links with non-Soviet neighbours such as Poland, Hungary, Romania and Turkey (in the west) and Iran, India and China (in the south and east). Examples include numerous economic agreements between Ukraine and the states of east-central Europe facilitated by the BSEC; development of economic infrastructure and rapidly growing trade between Kazakhstan, Uzbekistan, Azerbaijan, Georgia and Turkey, spearheaded by the Eurasian Transport Corridor (Transeca); and various steps to political and economic cooperation between Kazakhstan, Kyrgyzstan and China. Similarly, piecemeal integration has developed through cross-border agreements between former Soviet countries and their frontier provinces- 'peace bridges' linking countries together without customs checkpoints; cultural and educational linkages; and free economic trade zones.

Arguably, none of these relationships has been as critical for the survival of independent sovereignty in the non-Russian NIS as will be the role of foreign-primarily American and European, but also Asian and Middle Eastern-capital. Multinational companies have more influence over southern tier leaders than many of their parent governments. While they may align themselves with Russian partnerships as often as they collude in local efforts to evade Russian influence, these entrepreneurs do bring to the region a mentality that demystifies borders. By definition, their interest is in the southern tier as a region of transit as well as of resources. Particularly through the side-effects of their dealings in the financial and services sector, multinationals expose NIS economic and civic life to globalizing influences, thus providing an alternative to the EU's classic role as a stimulant for transnational thinking.

A further influence too often overlooked is the involvement of several NIS states in existing, CEE-led sub-regional ventures. Belarus is a member of the Central European Initiative (a I6-state group roughly covering the old Habsburg Empire); Ukraine belongs both to the CEI and to BSEC, and is probing the possibility of CEFTA membership; Moldova, Georgia, Armenia and Azerbaijan are all in the BSEC. By this token, all the western NIS and Caucasian states have committed themselves to the cooperative policies of the

I9 OMRI Daily Digest, 3 March 1997.

20 OMRI Daily Digest, r3 Jan. I997. 
relevant bodies and - in the case of the BSEC-have done so sitting alongside Russia as partners of equal status. The BSEC's far-reaching commitments include combating pollution, international crime, drug trafficking and terrorism, and the seminal policy document of the BSEC interior ministers on these issues was actually signed in Yerevan in 1996. The CEI and the BSEC both offer opportunities for engaging non-state and sub-state actors from the concerned NIS states, through the operation of their subordinate municipal, educational, cultural, business and parliamentary fora.

\section{Ways ahead?}

Any policy prescription which aims to do more than commend these positive elements must recognize the different environments for sub-regionalism in the western NIS and in the southern tier. In the west, the bottom-up conditions for benign, truly integrative sub-regional relations hinge essentially on economic factors. The fundamental challenges to Ukrainian stability are not whether the Russians in Crimea will secede, or how to divide the rusting Black Sea fleet, but rather the problem of raising the morale of Donbas miners while managing inflation and increasing productivity. Crimea may well become a threat of international proportions, but only if the Ukrainian economy deteriorates to the point where Russian activism offers profits exceeding the evident risks. Similarly, Belarus's hunger for political union with Russia has less to do with dubious nationhood than with the risk of starvation in its imploding economy. But the longer-term survival of Minsk as a Europeân capital will also demand greater Western (including central European) stimulus to Belarusan economic development-which need not conflict with Russian interests so long as the West respects Belarus's strategic allegiance and the transit routes through Belarusan land are opened up for both ends' advantage. Only if the economic equations turn negative will new political scope and motive invite Russian intervention.

That said, the fate of sub-regional relations in this area is also inescapably a function of Russia's relationship with the 'wider West'. The debate over NATO's first enlargement has shown how hard it is for Russians to accept that even the clearly independent nations of central Europe can move closer to the West without turning hostile backs on Moscow. To accept any degree of 'both-and' solutions-including permanent EU and NATO influence, if not membership - for territories previously within the Soviet Union is a severe test for even the most modern-minded Russian patriot. If Russia-West relations were to worsen as the century's end approaches, the degree of tolerance so far extended by Moscow to Ukraine's, Moldova's and Belarus's sub-regional forays could be called into question. (The consequences are unwelcome to contemplate precisely because Russia has no simple means of reining its neighbours in.) Conversely, if a modus vivendi can be sustained at the higher Euro-Atlantic strategic level, there should be scope for using the familiar and 
non-threatening devices of sub-regional and cross-border cooperation to strengthen integrative influences over all western NIS, to Russia's ultimate advantage as well. The risk of Russian misapprehension should be particularly small if this process is carried on transparently in fora where Russia already belongs; in this context the Council of Baltic Sea States (including Russia) needs to show more flexibility in finding a new status to accommodate Belarus's expressed interest in its work.

At best, a further strengthening of sub-regionalism along Russia's western front could chip away some of the psychological resistance to similar 'both-and' solutions for the south. Russian perception of how Turkish strategic motives are mediated or constrained by the practice of Black Sea Economic Cooperation could be one obvious bridging factor. But the bottom-up dynamics for actors in the southern tier will remain significantly different from those in the west. Recent ceasefires and the containment, rather than solution, of the Chechnya situation may have opened up some prospects for more positive relations, but the leap into real-time economic integration still hinges upon the resolution of political conflict. To maintain its statehood, the Georgian leadership must tackle irredentism from breakaway republics within, and Russian interference with political and economic development. Armenia's development is predicated upon the resolution-or continued prosecution-of war over Karabakh. Kazakhstan must accept political compromise with Russia on a host of basic security issues for any near-term hope of substantial oil export. Economic development-international investment, pipeline construction and the rebuilding of infrastructure-will not be free to follow its own non-zero-sum logic until fundamental political problems have been resolved. Any advance towards a region-wide cooperative security structure with appropriate subregional elements is bound to be painfully slow, but it is also going to have to accommodate a kind of variable geometry beyond anything known in western Eurasia. Russia's more-than-equal status cannot be ignored, only palliated; and the real balances to it will come from other large powers' involvement-plus, ideally, some strengthening of the OSCE's normative overview-rather than any structural solution native to the southern tier region. For the same reason, the cross-regional ties that have been woven into Russia's strategic safety blanket - from Belarus to Kazakhstan, from Moscow to Tehran and New Delhiwill be a part of the pattern for the foreseeable future, and pragmatism would suggest accepting them for whatever genuine (voluntary or quasi-voluntary) integrative elements they contain. What the West can try to add, while avoiding further polarization of NIS choices, are options and elements of sub-regionalism which supplement and diversify these relations rather than compete with them.

For example, the presence of Armenia and Azerbaijan in BSEC could be more consciously exploited as an opportunity for these states to work in a multilateral setting on practical issues that unite them, compartmentalizing the Karabakh issue within BSEC as other members 
(Greece/Turkey, Turkey/Bulgaria, Russia/Ukraine) have done with their respective quarrels. The potential of the BSEC 'corridors', and of other member states' assistance in 'proximity talks' mode, could be particularly fruitful. Elsewhere in the southern tier, the West's limited political and economic levers could bring multiplier effects if they were directed to strengthening emergent habits of bottom-up cooperation on the functional agenda-new threats and environment-most appropriate to the region. Wherever possible, the issue of Russian participation in such initiatives should be discussed in terms of practical need, not strategic side-taking, and where Russia is involved the formalization and transparency of cooperative regimes should bring protection against misuse. Any schemes which engage Russian provincial authorities (or other non-state players) in their own right will have special value for stabilizing cross-frontier relations; but they must be approached with full consciousness of their delicacy for Moscow (which increases as the areas concerned grow more remote, so that optimism about reproducing the smooth engagement of Murmansk and Arkhangelsk in north-west Europe's Barents Euro-Arctic Council would be misplaced).

Another useful touchstone for policy on NIS cooperation would be: does it promote openness to global processes, and the chances of success in digesting them, or not? Many of the benign effects of transfrontier cooperation meet this criterion, but it would also imply paying greater attention to factors like English language training, introduction of new information technologies and improvement of public access to them, the nature of financial/fiscal systems and (however difficult to actualize) the rule of law.

An interesting consequence of this results-oriented approach would be a reassessment of the interplay between NIS sub-regional links and CIS integration. In the first place, our analysis suggests that-even leaving aside Russian reactions - it is not a good idea for the West to stimulate inter-NIS groupings based only on resistance to CIS integration. The de facto alliance in this regard of Georgia, Moldova, Ukraine and Uzbekistan may be a political fact but formalizing it would bring no benefit in terms of economic integration, functional cooperation, internal democratization or (by definition) cross-border ties. It would merely harden the lines between these states and their immediate neighbours, and strengthen the reservations which the more pro-CIS states are bound to have anyway about joining in any additional (i.e. non-Russia-driven) sub-regional processes. The same test would, by contrast, bring out the value of new alignments which might develop within the existing sub-regional frames and in pursuit of positive shared interests, such as Moldovan/Ukrainian/Romanian cooperation in CEI following the latest advances in Romanian/Ukraine relations, or an emergent dialogue between all three Caucasian republics.

On this philosophy and with many mutandis to be mutatis, sub-regional ties could come to possess some of the same value in overcoming intra-CIS divisions and strains as they do already between NATO's members, 
non-members and critics in the West. The existing European groups offer an excellent model of 'non-security but pro-security' organizations, which succeed in easing tensions by ignoring them-sitting down together, sometimes even with open combatants, to address other, more common concerns about their national survival and welfare. In the NIS sphere as in central/eastern Europe, they will never replace the mechanisms for states' direct defence protection nor do anything directly to resolve their political disputes. They will never have the normative glamour, let alone economic significance, of the 'vision' of EU-style integration. For a region in the early stages of transition, needing more modest, evolutionary and frankly messy prescriptions, that is precisely the secret of sub-regionalism's appeal. ${ }^{2 \mathrm{I}}$

There is a final argument to be made about Russia. The political and public obsession with NATO enlargement since I994 has not only distracted Russia from a true prioritization of its security problems on the western, southern and eastern fronts, but has also encouraged Western tunnel vision, Eurocentricity and (because of the divisive effects) Europessimism. Western business has, admittedly, meanwhile been increasing its stake in the Caspian oilfields and Russian-Chinese relations have hit the headlines, but both have risked being read by non-cognoscenti in the same zero-sum context: as an anti-Russian asset in the first case and an anti-NATO alliance in the second. The first step that needs to be taken back towards a more balanced view is to appreciate the special, autonomous features of the southern tier's security environment-as briefly outlined above. The second is to remind ourselves that we are, after all, dealing with the same Russia throughout. It can hardly assist clear and cooperative thinking in Moscow if the same NATO leaders who are offering equal partnership in the advancement of European security, through a NATO/Russia Founding Act, treat Russia as the strategic adversary to be conspired against in the central Eurasian zone where its de facto influence is greater. On the other side, Russia can never be a fully trusted and credible partner for the West on European and global security issues if it persists in Jekyll-and-Hyde-like behaviour in its own neighbourhood.

Extending the analysis of sub-regionalism in coherent, though practically adapted, terms from 'core' Europe to the NIS region is a modest step away from such kinds of dual standards: and also away from the Manichaean thinking that would strand Europe behind a cosmos-chaos divide. In politics, unlike physics, entropy does not have to increase, and the stretching of existing concepts and systems of order to new regions can actually help revitalize them at the point of origin. For the West, recognizing the potential of those less glamorous institutions that are more easily stretchable could be the beginning of wisdom in this context. The difficulty of bridging eastward and southern divides

\footnotetext{
${ }^{21}$ For more on the application of sub-regionalism in central/eastern Europe and the NIS, see 'Sub-regional cooperation in the new Europe: current issues and future prospects', summary of an intergovernmental conference, Institute for EastWest Studies, Bratislava, 7-8 April 1997.
} 
is partly in our minds, and none the less serious for being so. The prize could include new hope, in the longer term, of succeeding with the greater challenge of transforming Russian hegemonism into integrative statesmanship. 